Please do not remove this page

RMIT

UNIVERSITY

\title{
How different are higher education institutions in the UK, US and Australia? The significance of government involvement
}

Moodie, Gavin

https://researchrepository.rmit.edu.au/esploro/outputs/9921859448901341/filesAndLinks?institution=61RMIT_INST\&index=null

Moodie, G. (2015). How different are higher education institutions in the UK, US and Australia? The significance of government involvement. Higher Education Quarterly, 69(1), 3-36.

https://doi.org/10.1111/hequ.12052

Document Version: Accepted Manuscript

Published Version: https://doi.org/10.1111/hequ.12052

Repository homepage: https://researchrepository.rmit.edu.au

(c) 2014 John Wiley and Sons Ltd

Downloaded On 2023/04/26 20:16:40 +1000

Please do not remove this page 
Thank you for downloading this document from the RMIT Research Repository.

The RMIT Research Repository is an open access database showcasing the research outputs of RMIT University researchers.

RMIT Research Repository: http://researchbank.rmit.edu.au/

\section{Citation:}

Moodie, G 2015, 'How different are higher education institutions in the UK, US and Australia? The significance of government involvement', Higher Education Quarterly, vol. 69 , no. 1 , pp. 3-36.

See this record in the RMIT Research Repository at:

https://researchbank.rmit.edu.au/view/rmit:31280

Version: Accepted Manuscript

Copyright Statement: (c) 2014 John Wiley and Sons Ltd

Link to Published Version:

http://dx.doi.org/10.1111/hequ.12052 
This is the accepted version of:

Moodie, Gavin (2014) How different are higher education institutions in the UK, US and Australia? The significance of government involvement, Higher Education Quarterly, DOI: 10.1111/hequ.12052.

\begin{abstract}
Most empirical analyses of the diversity of higher education systems use categorical variables, which shape the extent of diversity found. This study examines continuous variables of institutions' enrolment size and proportions of postgraduate, fulltime and international students to find the extent of variation amongst doctoral granting and all higher education institutions in the UK, US and Australia. The study finds that there is less variety amongst all higher education institutions in the UK than in Australia, which in turn has much less variety than the US. This suggests that the extent of government involvement in higher education isn't so important for institutional variety as the form which it takes. More tentatively, the paper suggests that the more limited the range of institutions for which government funding is available the stronger government involvement is needed to have variety among the limited range of institutions for which government financial support is available.
\end{abstract}

Gavin Moodie is adjunct professor of education at RMIT, Melbourne. He is interested in the relations between vocational and higher education. 
How different are higher education institutions in the UK, US and Australia? The significance of government involvement

Gavin Moodie, RMIT, Gavin.Moodie@telstra.com

Keywords: differentiation, diversity, government planning, UK, US, Australia.

\section{Introduction}

Huisman (1995) notes that higher education scholars adopted the terms 'differentiation' and 'diversity' from biology and more specifically from ecology which studies amongst other things the diversity, distribution, mass and number of organisms (The British Ecological Society, 2013). A key concept and basic unit of analysis in biology and ecology is the species, which is commonly defined as a group of organisms that can reproduce with one another in nature and produce fertile offspring (Nature Education, 2013). Huisman (1995, p. 7) argues that these terms should be used in higher education precisely. He defines 'differentiation' as 'a process indicating an increase of the number of entities' or 'a process in which a specific entity emerges (in a larger unit)', deriving this definition from biological differentiation which is a process in which different structures or functions develop from a formerly integrated whole. Huisman gives as an example of differentiation a university department which used to integrate teaching and research but which now separates them. Huisman (1995, p. 8) defines 'diversity' as 'the variety of types and dispersion of entities across these types' and 'diversification' as 'an increase in the number of types and/or dispersion of entities across these types' or as 'an increase of differences between entities or types'.

On this understanding biology's species becomes higher education's type and just as species is a fundamental taxonomic unit of biological classification so type of higher education unit is fundamental to considering higher education's diversity and diversification. Yet while there is a precise definition of species based on organisms' biological nature, there is (as yet) no such precise definition of type of higher educational institution based on their nature. As Huisman (2000, p. 43) observes 'it all boils down to the question of how to define species in higher education'. Analysts define institutional types from what seem salient characteristics. Two methods have been commonly used. One is to group institutions by similarities in their statistical properties. Cluster analysis is commonly used, but other techniques are available. Stanley and Reynolds (1994, p. 366) applied cluster analysis to ratings of Australian universities in 1993 and conducted another analysis of statistics on Australian universities in 1993. They found that 'it is not possible to obtain consistent simple clusterings for the majority of universities', and that the clusters they found did not reflect 'a natural grouping of the universities based on the history of their establishment' (Stanley and Reynolds, 1994, p. 363). Andrews, Aungles, Baker and Sarris (1998, p. 18) used principal components analysis to reduce eleven variables of Australian higher education institutions to four summary factors. They used these summary factors of 1997 data to group 43 institutions into six clusters (Andrews, Aungles, Baker and Sarris, 1998, p. 22). Again, Andrews and colleagues’ groupings of universities did not have face validity and neither theirs nor Stanley and Reynolds' clusters have been used extensively if at all in subsequent analyses of Australian universities. 
Another way of identifying types of higher education institutions is to choose characteristics that seem important or distinctive of higher education institutions and group institutions by those characteristics. For example, Birnbaum (1983) found 141 types of institutions from various combinations of their control, size of enrolments, sex of students, programme, highest level of degree offered and proportion of minority enrollment. This approach is subject to the way categories are specified and thus as Huisman (1995, p. 27) observes ' . . . the classification results are largely determined by the choice of the indicators or variables ... . For example, for their analysis of the diversity of higher education institutions in ten OECD countries Huisman, Meek and Wood (2007, p. 567) considered five categories of enrolment size: fewer than 101 students, 101-500 students, 501-3,000 students, 3,001-10,000 students and 10,000 or more students. They state that 'These categories were established to reflect the view that students probably will not experience the difference between institutes of 11,000 and 25,000 students, but will notice the difference between higher education institutions of 70 and 800 students' (Huisman, Meek and Wood, 2007, p. 567). This may be true, but they offer no evidence in support. Conway, Zhao and Montgomery (2011, pp. 17-18) report that while the size of institutions affects some dimensions of the national survey of student engagement, it does not effect other dimensions. They classified institutions into three size categories: small (fewer than 6,500), medium (12,000 to 21,000) and large (24,500 plus) (Conway, Zhao and Montgomery, 2011, p. 46) which are rather different from and markedly bigger than Huisman, Meek and Wood's categories of institutions' size. Morphew (2009, p. 253) seeks to reduce the element of judgement in defining categories by establishing categories at 'natural cut points', but natural cut points in some series may not coincide with any natural cut points in other series. In 2007 all but five of Australia's 40 universities were in Huisman, Meek and Wood's biggest size category, suggesting low diversity on this criterion. However, as we shall see later, using a rather different method finds that Australian doctoral granting institutions are somewhat diverse by enrolment size.

Another salient differentiator of higher education and indeed all educational institutions is the number and range of fields in which they teach and research. Thus, Rossi (2009) analysed the number of disciplines that Italian universities offered in bachelor and masters programmes in 14 groups. Rossi compared the number they offered in 1999-2000 with the number they offered six years later in 2005-06 to find that Italian universities became less diverse over the same period that competition between universities intensified. Rossi (2010, pp. 296-7) expanded her study to a cluster analysis of universities' enrolment size, specialization and mission-orientation to find that over the period studied Italian universities increased their differentiation in research intensity. She concludes that increased competition for students and research funds between universities has different effects on different characteristics of the system (Rossi (2010, p. 297).

This study avoids the limitations and perhaps somewhat arbitrary nature of the categorical variables that have been used in many analyses of higher education institutions' diversity by analysing only continuous variables such as enrolment numbers. Continuous variables do not rely on identifying institutional types, either by statistical analysis or by designating categories that seem salient. This paper uses the relative standard deviation to find the level of variation amongst institutions in a system and compares this with relative standard deviations in other systems to form a view of how varied systems are. This is used to test Birnbaum's (1983, pp. 149-182) argument that government planning inhibits institutional diversity, which Huisman (1995, p. 12) notes has not been tested. 


\section{Relative standard deviation}

The relative standard deviation is illustrated by examining enrolments in Russell Group universities, shown in table 1 . The mean of the Russell Group universities' total domestic enrolments in 2010/11 was 17,867 students. The median or mid point of Russell Group's total enrolments was 17,955 students, which is close to the mean. This indicates a fairly even distribution of institutions by this measure.

Table 1: domestic higher education enrolments of Russell Group universities by broad level, 2010/11

\begin{tabular}{lrrrr}
\hline Institution & Postgrad & Undergrad & Total & $\begin{array}{r}\text { Pgrad } \\
\text { \% of } \\
\text { total }\end{array}$ \\
& & & & 21.2 \\
\hline Cardiff University & 4,945 & 18,400 & 23,345 & 38.3 \\
\hline Imperial College & 3,500 & 5,645 & 9,145 & 32.5 \\
\hline King's College London & 6,250 & 13,010 & 19,260 & 31.3 \\
\hline LSE & 1,010 & 2,215 & 3,225 & 17.5 \\
\hline Queen Mary and Westfield College & 1,885 & 8,900 & 10,785 & 19.5 \\
\hline The Queen's University of Belfast & 4,240 & 17,450 & 21,690 & 29.9 \\
\hline The University of Birmingham & 7,260 & 17,005 & 24,265 & 21.8 \\
\hline The University of Bristol & 3,435 & 12,355 & 15,790 & 28.7 \\
\hline The University of Cambridge & 4,110 & 10,200 & 14,310 & 24.2 \\
\hline The University of Edinburgh & 4,475 & 14,020 & 18,495 & 21.2 \\
\hline The University of Exeter & 2,875 & 10,685 & 13,560 & 17.0 \\
\hline The University of Glasgow & 3,725 & 18,220 & 21,945 & 17.5 \\
\hline The University of Leeds & 4,685 & 22,125 & 26,810 & 14.1 \\
\hline The University of Liverpool & 2,390 & 14,565 & 16,955 & 22.2 \\
\hline The University of Manchester & 6,645 & 23,275 & 29,920 & 20.6 \\
\hline The University of Newcastle & 3,245 & 12,515 & 15,760 & 20.5 \\
\hline The University of Nottingham & 5,450 & 21,135 & 26,585 & 20.4 \\
\hline The University of Oxford & 3,730 & 14,565 & 18,295 & 22.6 \\
\hline The University of Sheffield & 4,525 & 15,460 & 19,985 & 21.1 \\
\hline The University of Southampton & 3,780 & 14,175 & 17,955 & 29.4 \\
\hline The University of Warwick & 5,770 & 13,825 & 19,595 & 2,4 \\
\hline The University of York & 2,610 & 10,190 & 12,800 & 20.4 \\
\hline University College London & 6,550 & 8,780 & 15,330 & 42.7 \\
\hline University of Durham & 2,780 & 10,220 & 13,000 & 21.4 \\
\hline Mean & 4,161 & 13,706 & 17,867 & 23.3 \\
\hline Standard deviation & 1,611 & 5,049 & 6,103 & 34 \\
\hline Relative standard deviation & 39 & 37 & & \\
\hline & & & & \\
\hline
\end{tabular}

Source: extracted from Higher Education Statistics Agency Limited) (2012) Students in higher education institutions 2010/11.

http://www.hesa.ac.uk/component/option,com_pubs/Itemid,286/task,show_year/pubId,1/versi onId,25/yearId,265/, Table 1 - all students by HE institution, level of study, mode of study and domicile 2010/11, last accessed 16 July 2012. 
The standard deviation of the Russell Group's total enrolments was 6,103, which is only just over a third of the mean. This indicates that there wasn't much variation in Russell Group total enrolments. A formal comparison of the mean and standard deviation and hence of variation in values is the coefficient of variation, which is the ratio of the standard deviation to the mean or the standard deviation divided by the mean. The variation coefficient expressed as a percentage is the relative standard deviation (RSD) -

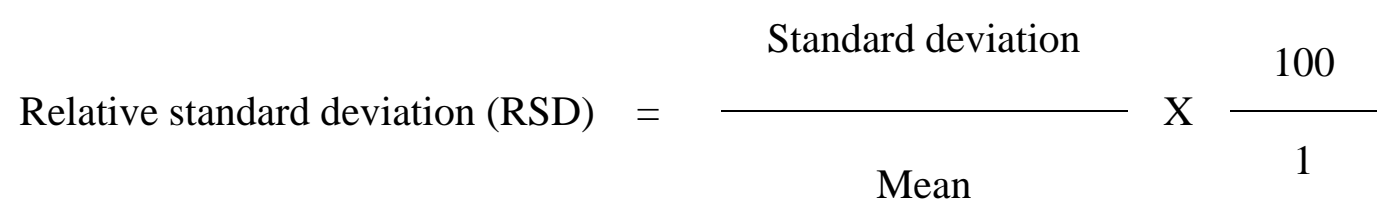

A relative standard deviation of less than 50 indicates very little dispersion, a coefficient of around 100 indicates moderate dispersion and an RSD of more than 100 indicates considerable dispersion of values. It will be noted from Table 1 that in 2010/11 Russell Group universities were homogenous not only in their total number of domestic enrolments but also in their number and proportion of postgraduate enrolments.

The paper compares enrolment data in the UK, the US and Australia. These countries not only have different data collections, but different understandings of key terms such as 'higher education' and 'university'. For the purposes of this paper 'higher education' is defined as bachelor program or above, which is consistent with the international standard classification of education (UNESCO, 2006; OECD, 2013, pp. 32-51). Because of differences in the definitions and even understandings of what is a university in the UK, Australia and in different states of the USA, the paper considers not universities but doctoral granting institutions. Doctoral granting institutions are somewhat and differently broader than universities in the UK and Australia but are narrower than universities in the US. Each US doctoral program includes extensive coursework and advanced seminars which most institutions cannot afford to mount without an intake of at least five to ten new students in each field each year. In addition, several US states do not regulate the university title as restrictively as Australia and even the UK's recently relaxed requirements, so several US universities do not offer doctoral programs. In the latest years for which data are available doctoral granting institutions enrolled 99 per cent of all higher education students in the UK, 94 per cent of higher education students in Australia but only 43 per cent of higher education students in the US.

We now consider the relative standard deviation of some basic enrolment data for UK higher education institutions which we will later compare with the same measure of similar data for US and Australian higher education institutions to form a view on the extent of differences in higher education institutions in the UK, US and Australia.

\section{United Kingdom}

The Higher Education Statistics Agency Limited publishes standard statistics on higher education enrolments in the UK. Data on domestic undergraduate and postgraduate enrolments in 2010/11 for each institution reported by the Agency as offering a bachelor degree or above are summarized in Table 2. Institutions were analysed as the Agency listed them, although as the agency notes, 19 institutions are members of the University of London 'confederation', including King's College London, LSE (London School of Economics and Political Science), Queen Mary and Westfield College, and University College London which are members of the Russell Group in their own right. 
The relative standard deviation for the 154 UK doctoral granting institutions' undergraduate enrolments in 2010/11 was 149 . This is a very high value and indicates very considerable variation in the undergraduate size of UK doctoral granting institutions. This is because the UK has six doctoral granting agricultural and creative arts institutes with small undergraduate enrolments of around 500 or fewer, four universities with only postgraduate enrolments such as Cranfield and the London School of Hygiene and Tropical Medicine, as well as the very big Open University with 194,940 undergraduates. The RSD for UK doctoral granting institutions' postgraduate enrolments is a modest 86, indicating relatively little variation in the size of postgraduate enrolments. Accordingly the RSD for proportion of postgraduates is also a relatively homogenous 84 . The relative standard deviation for total enrolments of UK doctoral granting institutions was 133, which still indicates considerable variation in total institutional enrolments. However, the RSD for total enrolments of 133 is somewhat less than the RSD for undergraduate enrolments of 149, indicating that the variation in the size of total enrolments was moderated by the low variation of 86 in postgraduate enrolments.

Only ten UK higher education institutions don't grant doctorates, most of which are creative arts academies, and two non doctoral granting academies supervise doctorates awarded by collaborating universities. Non doctoral granting institutions increase UK institutions' relative standard deviations by around 5 points, indicating that because of their small number they don't add much to this measure of variation amongst UK higher education institutions.

Table 2: summary statistics on UK institutions’ domestic higher education enrolments by broad level, 2010/11

\begin{tabular}{lrrrr}
\hline Type of institution (number) & Postgrad & Undergrad & Total & $\begin{array}{r}\text { Postgrad as \% } \\
\text { of total }\end{array}$ \\
\hline Doctoral granting institutions (154) & & & & \\
\hline Total & 374,060 & $1,690,780$ & $2,064,840$ & 18 \\
\hline Mean & 2,429 & 10,979 & 13,408 & 23 \\
\hline Standard deviation & 2,097 & 16,364 & 17,773 & 19 \\
\hline Relative standard deviation & 86 & 149 & 133 & 84 \\
\hline All institutions (164) & \multicolumn{4}{r}{} \\
\hline Total & 375,030 & $1,698,040$ & $2,073,070$ & 18 \\
\hline Mean & 2,287 & 10,354 & 12,641 & 23 \\
\hline Standard deviation & 2,108 & 16,044 & 17,482 & 19 \\
\hline Relative standard deviation & 92 & 155 & 138 & 85 \\
\hline
\end{tabular}

Source: extracted from Higher Education Statistics Agency Limited) (2012) Students in higher education institutions 2010/11, retrieved 16 July 2012 from

http://www.hesa.ac.uk/component/option,com_pubs/Itemid,286/task,show_year/pubId,1/versi onId,25/yearId,265/, Table 1 - all students by HE institution, level of study, mode of study and domicile 2010/11

We now compare the variation amongst institutions by broad study load - whether their students study full time or part time (Table 3). Table 3 summarizes figures for all students studying onshore including international students, not just the domestic students reported in Table 2. The inclusion of onshore international students reduces the RSD for total enrolments in doctoral granting and non doctoral granting institutions from 133 and 138 to 113 and 119 . This indicates that there is a more even distribution of international onshore students than domestic students, which might be the result of earlier government decisions to allocate places for domestic students preferentially to some institutions such as public universities and colleges. 
The relative standard deviation for all UK higher education institutions' number of part time students is a very high 325. This is because of the Open University which enrolled 208,705 onshore students in 2010/11, only 305 or 0.1 per cent of whom were full time. This is illustrated by the much lower RSD of 92 when the Open University is excluded from the analysis. However, the Open University should not be excluded from the analysis as an outlier because it is just this significantly distinctive provision which the analysis is seeking to consider. There is reasonably low variation in the size of UK institutions' onshore full time enrolments.

Table 3: summary statistics of UK higher education institutions' onshore students by broad study load, 2010/11

\begin{tabular}{|c|c|c|c|c|}
\hline Type of institution & Full time & Part time & Total & $\begin{array}{r}\text { Full time as \% } \\
\text { of total }\end{array}$ \\
\hline \multicolumn{5}{|l|}{ Doctoral granting institutions } \\
\hline Total & $1,668,360$ & 823,055 & $2,491,415$ & 67 \\
\hline Mean & 10,834 & 5,345 & 16,178 & 73 \\
\hline Standard deviation & 7,452 & 16,823 & 18,347 & 16 \\
\hline Relative standard deviation & 69 & 315 & 113 & 22 \\
\hline \multicolumn{5}{|l|}{ All institutions } \\
\hline Total & $1,677,345$ & 823,955 & $2,501,300$ & 67 \\
\hline Mean & 10,228 & 5,024 & 15,252 & 75 \\
\hline Standard deviation & 7,604 & 16,348 & 18,146 & 16 \\
\hline Relative standard deviation & 74 & 325 & 119 & 22 \\
\hline \multicolumn{5}{|l|}{ All institutions without OU } \\
\hline Total & $1,677,015$ & 615,545 & $2,292,560$ & 73 \\
\hline Mean & 10,288 & 3,776 & 14,065 & 75 \\
\hline Standard deviation & 7,587 & 3,466 & 9,944 & 15 \\
\hline Relative standard deviation & 74 & 92 & 71 & 20 \\
\hline
\end{tabular}

Source: extracted from Higher Education Statistics Agency Limited (2012) Students in higher education institutions 2010/11, retrieved 16 July 2012 from

http://www.hesa.ac.uk/component/option,com_pubs/Itemid,286/task,show_year/pubId,1/versi onId,25/yearId,265/, Table 1 - all students by HE institution, level of study, mode of study and domicile 2010/11

The UK's Higher Education Statistics Agency reports on shore students by domicile, distinguishing between international students from other European Union countries and those from non EU countries. This distinction is important in the UK because the European Union requires member states to charge students from other EU countries the same fees as the host country's domestic students. There are therefore grounds for including students from other EU countries with domestic students, for including other EU students with non EU international students or for excluding them from the analysis. The treatment of other EU students isn't crucial because they are only 5.2 per cent of all students (Table 4). In this paper other EU students are included with non EU international students because international students from EU countries require different recruitment, cultural and language support; and because they increase the diversity of the host institution almost as much as other international students. Furthermore, institutions outside the EU compete with UK and other institutions for students from other EU countries. 
Table 4: onshore UK students by domicile, 2010/11

\begin{tabular}{lrrrrr}
\hline Measure & UK & Other EU & Non EU & $\begin{array}{r}\text { All } \\
\text { international }\end{array}$ & Total \\
\hline Postgraduate & & & & & \\
\hline Students & 375,030 & 49,795 & 163,890 & 213,685 & 588,720 \\
\hline \% of all postgraduates & 63.7 & 8.5 & 27.8 & 36.3 & 100.0 \\
\hline Undergraduate & & & & & \\
\hline Students & $1,698,040$ & 80,320 & 134,220 & 214,540 & $1,912,580$ \\
\hline \% of all undergraduates & 88.8 & 4.2 & 7.0 & 11.2 & 100.0 \\
\hline All students & & & & & \\
\hline Students & $2,073,070$ & 130,115 & 298,110 & 428,225 & $2,501,300$ \\
\hline$\%$ of all students & 82.9 & 5.2 & 11.9 & 17.1 & 100.0 \\
\hline
\end{tabular}

Source: extracted from Higher Education Statistics Agency Limited (2012) Students in higher education institutions 2010/11, retrieved 16 July 2012 from

http://www.hesa.ac.uk/component/option,com_pubs/Itemid,286/task,show_year/pubId,1/versi onId,25/yearId,265/, Table 1 - all students by HE institution, level of study, mode of study and domicile 2010/11

For the first time for 2010/11 the Higher Education Statistics Agency's standard reports include off shore enrolments by institution. Usefully, the Agency reports off shore enrolments by type of off shore provision: off shore campus, partnership, flexible learning and other arrangements (Table 5).

Table 5: UK offshore students by type of offshore provision, 2010/11

\begin{tabular}{|c|c|c|c|c|}
\hline $\begin{array}{l}\text { Students registered at a UK } \\
\text { HE institution }\end{array}$ & $\begin{array}{r}\text { Overseas } \\
\text { campus of } \\
\text { reporting HEI }\end{array}$ & $\begin{array}{r}\text { Distance, } \\
\text { flexible or } \\
\text { distributed } \\
\text { learning }\end{array}$ & $\begin{array}{r}\text { Other } \\
\text { arrangement } \\
\text { including } \\
\text { collaborative } \\
\text { provision }\end{array}$ & Total \\
\hline Students & 12,315 & 113,060 & 86,670 & 212,045 \\
\hline $\begin{array}{l}\text { \% of students registered at a } \\
\text { UK HE institution }\end{array}$ & 5.8 & 53.3 & 40.9 & 100.0 \\
\hline $\begin{array}{l}\text { Students studying for an } \\
\text { award of a UK HE institution }\end{array}$ & $\begin{array}{r}\text { Overseas } \\
\text { partner } \\
\text { organisation }\end{array}$ & & $\begin{array}{r}\text { Other } \\
\text { arrangement }\end{array}$ & Total \\
\hline Students & 291,595 & & 155 & 291,745 \\
\hline $\begin{array}{l}\text { \% of students studying for an } \\
\text { award of a UK HE institution }\end{array}$ & 99.9 & & 0.1 & 100.0 \\
\hline All off shore & Campus based & $\begin{array}{l}\text { Flexible } \\
\text { learning }\end{array}$ & Other & Total \\
\hline Students & 303,910 & 113,060 & 86,825 & 503,790 \\
\hline$\%$ of all off shore & 60.3 & 22.4 & 17.2 & 100.0 \\
\hline
\end{tabular}

Source: Higher Education Statistics Agency Limited) (2012) Students in higher education institutions 2010/11, retrieved 16 July 2012 from http://www.hesa.ac.uk/component/option,com_pubs/Itemid,286/task,show_year/pubId,1/versi onId,25/yearId,265/, Table 21 - students studying wholly overseas by HE institution and type of activity 2010/11 
Aggregating international student enrolments at UK higher education institutions into onshore and offshore will allow us to compare them later with the figures available in standard Australian statistical reports. The aggregated summary statistics for the UK are given in Table 6 . We note that the relative standard deviation (RSD) for off shore international students for all institutions is a very high 642. This is due mainly to Oxford Brookes University which enrolled 239,945 offshore international students in 2010/11, mostly with an overseas partner on Association of Chartered Certified Accountants programs. It will also be noted further that all institutions' relative standard deviation for offshore international students as a proportion of all students is a high 218. This is due mostly to the University of London's distance learning international programs which enrolled 44,050 international students offshore in 2010/11 but only 410 students onshore. Excluding Oxford Brookes and London's international distance learning programs lowers UK institutions' relative standard deviations, but again, excluding these institutions excludes the very variability that this analysis seeks to consider. There is little variation in UK institutions' international students as a proportion of all students, with an RSD of 68. However, there is considerable variety in UK institutions' proportion of off shore international students, with RSDs of 210 and 218. From this we may conclude that while many UK institutions have similar proportions of international students on shore, off shore provision is much more variable.

Table 6: summary statistics of UK institutions' international on shore and off shore enrolments, 2010/11

\begin{tabular}{|c|c|c|c|c|c|c|}
\hline Type of institution & Onshore & Offshore & $\begin{array}{r}\text { Sub total } \\
\text { international }\end{array}$ & $\begin{array}{r}\text { All } \\
\text { students }\end{array}$ & $\begin{array}{r}\text { International } \\
\text { as \% of all } \\
\text { students }\end{array}$ & $\begin{array}{r}\text { Off shore } \\
\text { as \% of all } \\
\text { students }\end{array}$ \\
\hline \multicolumn{7}{|c|}{ Doctorial granting institutions } \\
\hline Total & 426,600 & 488,355 & 914,955 & 2,979,795 & 31 & 16 \\
\hline Mean & 2,770 & 3,171 & 5,941 & 19,349 & 24 & 6 \\
\hline Standard deviation & 2,265 & 19,721 & 19,917 & 28,067 & 17 & 13 \\
\hline RSD & 82 & 622 & 335 & 145 & 68 & 210 \\
\hline \multicolumn{7}{|l|}{ All institutions } \\
\hline Total & 503,795 & 932,020 & 2,501,295 & $3,005,090$ & 31 & 17 \\
\hline Mean & 2,611 & 2,978 & 5,589 & 18,230 & 24 & 6 \\
\hline Standard deviation & 2,282 & 19,121 & 19,347 & 27,547 & 16 & 13 \\
\hline RSD & 87 & 642 & 346 & 151 & 68 & 218 \\
\hline \multicolumn{7}{|c|}{ UK without Oxford Brookes and University of London distance learning international programs } \\
\hline Total & 424,885 & 204,375 & 629,260 & $2,686,895$ & 25 & 8 \\
\hline Mean & 2,623 & 1,262 & 3,884 & 16,586 & 23 & 5 \\
\hline Standard deviation & 2,288 & 2,819 & 4,029 & 20,081 & 14 & 8.5 \\
\hline RSD & 87 & 224 & 104 & 121 & 62 & 172 \\
\hline
\end{tabular}

Sources: Higher Education Statistics Agency Limited) (2012) Students in higher education institutions 2010/11, retrieved 16 July 2012 from http://www.hesa.ac.uk/component/option,com_pubs/Itemid,286/task,show_year/pubId,1/versi onId,25/yearId,265/, Table 1 - all students by HE institution, level of study, mode of study and domicile 2010/11 and table 21 - students studying wholly overseas by HE institution and type of activity 2010/11.

We now examine variation amongst US higher education institutions. 


\section{United States of America}

Enrolment data for US higher education institutions were obtained from the US Department of Education's integrated postsecondary education data system. The Ipeds data center allows one to extract data on institutions on one of several variables. For this analysis data were extracted for public, private not for profit and private for profit four year institutions or above. This selected institutions which offered a baccalaureate or above.

Data were extracted for the 2,959 institutions that participated in federal financial aid programs, that is, whose students were eligible for federal grants and loans. The Department reports data on an additional 47 or 1.6 per cent of institutions which do not participate in Title IV grants. These weren't included in the analysis because some US states don't have any substantial quality assurance for higher education and Title IV eligibility is a useful indicator of meeting minimal standards. While this reduces the heterogeneity of the US data somewhat, diploma mills and other non Title IV participating institutions are probably undesirable heterogeneity.

Some 14 or 0.5 per cent of institutions reported no enrolment data so the final list had 2,945 institutions. There were 295 title IV institutions which were classified in the 2010 Carnegie classification as a doctoral/research university, research university (high research activity) or research university (very high research activity). Enrolments were extracted for Fall 2010, which are like enrolments at 1 August in the UK or first semester enrolments in Australia.

Results for domestic enrolments by broad level of study are summarized in Table 7. It will be noted that while there is considerable variation amongst doctoral granting institutions with relative standard deviations around 100, they are half as heterogeneous as all higher education institutions, which have relative standard deviations around 200.

Table 7: summary statistics of institutions' domestic higher education enrolments by broad level, Fall 2010

\begin{tabular}{lrrrr}
\hline $\begin{array}{l}\text { Type of institution } \\
\text { (number) }\end{array}$ & Postgrad & Undergrad & Total & $\begin{array}{r}\text { Postgrad as \% } \\
\text { of total }\end{array}$ \\
\hline Doctoral granting institutions (295 institutions) & & & \\
\hline Total & $1,421,879$ & $4,011,616$ & $5,433,495$ & 26 \\
\hline Mean & 4,820 & 13,599 & 18,419 & 31 \\
\hline Standard deviation & 4,866 & 16,609 & 20,115 & 19 \\
\hline RSD & 101 & 122 & 109 & 62 \\
\hline All institutions (2,945) & \multicolumn{5}{r}{} & & & \\
\hline Total & $2,659,013$ & $10,321,078$ & $12,980,091$ & 21 \\
\hline Mean & 903 & 3,505 & 4,408 & 31 \\
\hline Standard deviation & 2,255 & 7,527 & 9,236 & 135 \\
\hline RSD & 250 & 215 & 210 & \\
\hline
\end{tabular}

Source: Integrated Postsecondary Education Data System (2012) Race/ethnicity, gender, attendance status, and level of student, data extracted 26 July 2012 from http://nces.ed.gov/ipeds/datacenter/, Race/ethnicity, gender, attendance status, and level of student 
The results for broad study load are set out in Table 8. It will be noted that the variation in the numbers of full time, part time and total enrolments follow the pattern we have already observed, with variation amongst doctoral granting institutions, but about twice as much variation amongst all institutions. However, both doctoral granting and all four year institutions are not varied by proportion of full time students, with most institutions having about 75 per cent full time students. This is because most part time higher education students are enrolled in two year or community colleges and few four year colleges and universities specialize in part time students.

Table 8: summary statistics of institutions’ students by broad study load, Fall 2010

\begin{tabular}{lrrrr}
\hline Type of institution & Full time & Part time & Total & $\begin{array}{r}\text { Full time as \% } \\
\text { of total }\end{array}$ \\
\hline Doctoral granting institutions & & & & \\
\hline Total & $4,649,065$ & $1,184,745$ & $5,833,810$ & 80 \\
\hline Mean & 15,760 & 4,016 & 19,776 & 77 \\
\hline Standard deviation & 20,036 & 3,712 & 20,907 & 14 \\
\hline RSD & 127 & 92 & 106 & 19 \\
\hline All institutions & \multicolumn{4}{r}{} \\
\hline Total & $9,902,860$ & $3,683,585$ & $13,586,445$ & 73 \\
\hline Mean & 3,368 & 1,251 & 4,613 & 75 \\
\hline Standard deviation & 8,155 & 3,065 & 9,662 & 22 \\
\hline RSD & 242 & 245 & 209 & 29 \\
\hline
\end{tabular}

Source of US data: Integrated Postsecondary Education Data System (2012) Race/ethnicity, gender, attendance status, and level of student, data extracted 26 July 2012 from http://nces.ed.gov/ipeds/datacenter/, Race/ethnicity, gender, attendance status, and level of student

Unfortunately the US publishes data only for onshore international students. The summary statistics are shown in Table 9, which follow the patterns we have observed with domestic enrolments by broad study level.

Table 9: summary statistics of institutions' onshore international students as a proportion of all onshore students, Fall 2010

\begin{tabular}{lrrr}
\hline Type of institution & $\begin{array}{r}\text { Onshore } \\
\text { international }\end{array}$ & $\begin{array}{r}\text { All onshore } \\
\text { students }\end{array}$ & $\begin{array}{r}\text { Onshore international } \\
\text { as \% of all students }\end{array}$ \\
\hline Doctoral granting institutions & & & \\
\hline Total & 400,315 & $5,833,810$ & 6.9 \\
\hline Mean & 1,357 & 19,776 & 7.1 \\
\hline Standard deviation & 1,428 & 20,907 & 6 \\
\hline RSD & 105 & 106 & 4.5 \\
\hline All institutions & & & 3.3 \\
\hline Total & 606,354 & $13,586,445$ & 6.4 \\
\hline Mean & 206 & 4,613 & 194 \\
\hline Standard deviation & 627 & 9,662 & 209 \\
\hline RSD & 305 & $5 y 54$ & \\
\hline
\end{tabular}

Source of US data: Integrated Postsecondary Education Data System (2012) Race/ethnicity, gender, attendance status, and level of student, data extracted 26 July 2012 from http://nces.ed.gov/ipeds/datacenter/, Race/ethnicity, gender, attendance status, and level of student 
We now examine variation amongst Australian higher education institutions.

\section{Australia}

Unfortunately the Australian Government's higher education statistics do not include all enrolments of all private providers. The Australian Government doesn't collect statistics from about 50 private providers whose students are not eligible for government guaranteed and subsidized income contingent loans for tuition fees. It seems that some private institutions that report statistics report only their students supported by government loans and not their domestic students who do not take out a government loan nor international students. So the figures understate private providers' enrolments. A further methodological limit is that while the Australian Government department responsible for higher education published full enrolment data on non university providers until 2009, thereafter it has published only summary data for these institutions. So this analysis considers institutions' enrolments for the most recent year for which the department published full enrolment data, 2009.

Table 10 shows summary statistics for domestic enrolments in Australian higher education institutions by broad level of program for 2009. It will be noted that as in the US, Australian non doctoral higher education institutions approximately doubled the variation in postgraduate, undergraduate and total enrolments and proportion of postgraduate enrolments.

Table 10: summary statistics for Australian institutions' domestic higher education enrolments by broad level, 2009

\begin{tabular}{lrrrr}
\hline Type of institution (number) & Postgrad & Undergrad & Total & $\begin{array}{r}\text { Postgrad as \% } \\
\text { of total }\end{array}$ \\
\hline Doctoral granting institutions (48) & & & & \\
\hline Total & 191,573 & 571,361 & 762,934 & 25 \\
\hline Mean & 3,991 & 11,903 & 15,894 & 28 \\
\hline Standard deviation & 3,341 & 8,353 & 11,354 & 18 \\
\hline Relative standard deviation & 84 & 70 & 71 & 65 \\
\hline All institutions (114 institutions) & & & & \\
\hline Total & 197,619 & 594,408 & 792,027 & 25 \\
\hline Mean & 1,734 & 5,214 & 6,948 & 21 \\
\hline Standard deviation & $2,910.3$ & $7,877.9$ & $10,614.0$ & 27 \\
\hline Relative standard deviation & 168 & 151 & 153 & 128 \\
\hline
\end{tabular}

Source: extracted from Department Education, Employment and Workplace Relations (2010) Students 2009 full year, retrieved 10 December 2010 from http://www.deewr.gov.au/HigherEducation/Publications/HEStatistics/Publications/Pages/2009 FullYear.aspx, Table 2.6: all domestic students by State, higher education provider and broad level of course, full year 2009.

In broad study load we see a similar pattern of moderate dispersion amongst doctoral granting institutions but very high dispersion amongst all higher education institutions. However, for both groups there is little variation in the proportion of full time students, indicating that institutions have similar proportions of full time students whatever their type. 
Table 11: summary statistics for Australian institutions by broad study load, 2009

\begin{tabular}{lrrrr}
\hline Type of institution (number) & Full time & Part time & Total & $\begin{array}{r}\text { Full time as \% } \\
\text { of total }\end{array}$ \\
\hline Doctoral granting institutions & & & & \\
\hline Total & 745,354 & 316,772 & $1,062,126$ & 70 \\
\hline Mean & 15,528 & 6,599 & 22,128 & 68 \\
\hline Standard deviation & 12,264 & 4,959 & 16,336 & 16 \\
\hline Relative standard deviation & 79 & 75 & 74 & 24 \\
\hline All institutions & & & & 70 \\
\hline Total & 794,452 & 340,414 & $1,134,866$ & 66 \\
\hline Mean & 6,908 & 2,960 & 9,868 & 24 \\
\hline Standard deviation & 10,832 & 4,481 & 14,895 & 36 \\
\hline Relative standard deviation & 157 & 151 & 151 & \\
\hline
\end{tabular}

Source: extracted from Department Education, Employment and Workplace Relations (2010) Students 2009 full year, retrieved 10 December 2010 from http://www.deewr.gov.au/HigherEducation/Publications/HEStatistics/Publications/Pages/2009 FullYear.aspx, Table 2.7: all students by State, higher education provider, mode of attendance, type of attendance and gender, full year 2009

We now consider variations in Australian higher education institutions' numbers of onshore and offshore international students (Table 12). There is somewhat more variation in Australian institutions' number of international students than other measures we have considered, but there is much greater variation in the number and proportion of off shore international students than in the other measures considered. The relative standard deviation for number of off shore international students is a very high 187 for doctoral institutions, compared to these institutions' coefficients for full time students (79) and postgraduate students (84), and similarly with proportion of offshore students. There is even greater variation in number of offshore students amongst all institutions, with a very high relative standard deviation of 304 compared with these institutions' coefficients for full time students (157) and postgraduate students (168).

Table 12: summary statistics for Australian institutions by international on shore and off shore enrolments, 2009

\begin{tabular}{lrrrrr}
\hline Type of institution & Onshore & Offshore & $\begin{array}{r}\text { Sub total } \\
\text { international }\end{array}$ & $\begin{array}{r}\text { International } \\
\text { as \% of all } \\
\text { students }\end{array}$ & $\begin{array}{r}\text { Off shore } \\
\text { as of all } \\
\text { students }\end{array}$ \\
\hline Doctoral granting institution & & & & & \\
\hline Total & 22,924 & 73,650 & 296,574 & 28 & 7 \\
\hline Mean & 4,644 & 1,534 & 6,179 & 25 & 5 \\
\hline Standard deviation & 3,895 & 2,874 & 5,599 & 15 & 7 \\
\hline RSD & 84 & 187 & 91 & 61 & 136 \\
\hline All institutions & & & & & 29 \\
\hline Total & 245,593 & 75,377 & 320,970 & 29 & 3 \\
\hline Mean & 2,136 & 656 & 2,791 & 32 & 8 \\
\hline Standard deviation & 3,341 & 1,994 & 4,649 & 112 & 267 \\
\hline RSD & 157 & 304 & 167 & & \\
\hline
\end{tabular}


Sources: extracted from Department Education, Employment and Workplace Relations (2010) Students 2009 full year, retrieved 10 December 2010 from

http://www.deewr.gov.au/HigherEducation/Publications/HEStatistics/Publications/Pages/2009

FullYear.aspx, Table 2.5: all students by State, higher education provider and broad level of course, full year 2009 and table 7.7: commencing and all overseas students by State, higher education provider and onshore/offshore status, full year 2009

We are now able to compare variations in higher education institutions in the UK, US and Australia.

\section{Comparison of UK, US and Australian doctoral granting institutions}

We first compare summary statistics for UK, US and Australian doctoral granting institutions' domestic higher education enrolments by broad level (Table 13). We note, first, that the average domestic enrolment of Australian doctorial granting institutions $(15,894$ students) is bigger than that for the UK $(13,408)$ but less than that for the US $(18,419)$. We next note that domestic postgraduate students are about a quarter of students at all doctoral granting institutions in Australia and the US, but that they are rather lower in the UK (18\%).

Considering numbers of postgraduate students, there is moderate variation in UK and Australian doctoral institutions, with a relative standard deviation of around 85, but US doctoral institutions are more diverse with a relative standard deviation of 101 . This is partly due to the University of Phoenix, which has 307,965 enrolments, only 18 per cent of whom are postgraduate. UK and US doctoral institutions have considerable variations in their numbers of undergraduate students (coefficients of 149 and 122), much higher than Australian doctoral granting institutions (70). In proportion of postgraduates UK doctoral institutions have somewhat more variation (coefficient of 84) than Australian (65) and US (62) institutions.

Table 13: summary statistics for Australian, UK and US doctoral granting institutions' domestic higher education students by broad level

\begin{tabular}{|c|c|c|c|c|}
\hline Country & Postgrad & Undergrad & Total & $\begin{array}{r}\text { Postgrad } \\
\text { as \% of total }\end{array}$ \\
\hline \multicolumn{5}{|c|}{ Australia, 2009 (48 institutions) } \\
\hline Total & 191,573 & 571,361 & 762,934 & 25 \\
\hline Mean & 3,991 & 11,903 & 15,894 & 28 \\
\hline Standard deviation & 3,341 & 8,353 & 11,354 & 18 \\
\hline Relative standard deviation & 84 & 70 & 71 & 65 \\
\hline \multicolumn{5}{|c|}{ UK, 2010/2011 (154 institutions) } \\
\hline Total & 374,060 & $1,690,780$ & $2,064,840$ & 18 \\
\hline Mean & 2,429 & 10,979 & 13,408 & 23 \\
\hline Standard deviation & 2,097 & 16,364 & 17,773 & 19 \\
\hline Relative standard deviation & 86 & 149 & 133 & 84 \\
\hline \multicolumn{5}{|c|}{ US, Fall 2010 (295 institutions) } \\
\hline Total & $1,421,879$ & $4,011,616$ & $5,433,495$ & 26 \\
\hline Mean & 4,820 & 13,599 & 18,419 & 31 \\
\hline Standard deviation & 4,866 & 16,609 & 20,115 & 19 \\
\hline Relative standard deviation & 101 & 122 & 109 & 62 \\
\hline
\end{tabular}


Table 14 examines all enrolments of doctoral granting institutions (not just domestic students) by broad study load. UK doctoral institutions have an average total enrolment of 16,178 students, rather smaller than US (19,776 students) and much smaller than Australian $(22,126)$ institutions. Full time students are 67 per cent of UK doctoral institutions' total enrolments, not much different from Australia (70 per cent) but both are much less than the US (80 per cent) where most part time students enrol in two year or community colleges. UK doctoral institutions are very varied in their total enrolments (coefficient of 113), just a little more than the US (106) and rather more than Australia (74). There is very considerable variation in UK doctoral institutions' number of part time students (coefficient of 315) which we saw was due mostly to the UK Open University’s very big enrolment of part time students.

Table 14: summary statistics for Australian, UK and US doctoral institutions' students by broad study load

\begin{tabular}{|c|c|c|c|c|}
\hline Country & Full time & Part time & Total & $\begin{array}{r}\text { Full time as \% } \\
\text { of total }\end{array}$ \\
\hline \multicolumn{5}{|c|}{ Australia, 2009 (48 institutions) } \\
\hline Total & 745,354 & 316,772 & $1,062,126$ & 70 \\
\hline Mean & 15,528 & 6,599 & 22,128 & 68 \\
\hline Standard deviation & 12,264 & 4,959 & 16,336 & 16 \\
\hline Relative standard deviation & 79 & 75 & 74 & 24 \\
\hline \multicolumn{5}{|c|}{ UK, 2010/2011 (154 institutions) } \\
\hline Total & $1,668,360$ & 823,055 & $2,491,415$ & 67 \\
\hline Mean & 10,834 & 5,345 & 16,178 & 73 \\
\hline Standard deviation & 7,452 & 16,823 & 18,347 & 16 \\
\hline Relative standard deviation & 69 & 315 & 113 & 22 \\
\hline \multicolumn{5}{|c|}{ US, Fall 2010 (295 institutions) } \\
\hline Total & $4,649,065$ & $1,184,745$ & $5,833,810$ & 80 \\
\hline Mean & 15,760 & 4,016 & 19,776 & 77 \\
\hline Standard deviation & 20,036 & 3,712 & 20,907 & 14 \\
\hline Relative standard deviation & 127 & 92 & 106 & 19 \\
\hline
\end{tabular}

As we see from Table 15, UK doctoral institutions have an average of 2,700 on shore international students, more than double US doctoral institutions $(1,357)$ but rather fewer than Australia $(4,644)$. Consequentially, onshore international students are a higher proportion of all onshore students in UK doctoral institutions (17 per cent) than US institutions (6.9 per cent) but rather lower than in Australian institutions (23 per cent). UK and Australian institutions have rather less variation than US institutions in their number and proportion of onshore international students.

Table 15: summary statistics for Australian, UK and US doctoral granting institutions' onshore international students as a proportion of all onshore students

\begin{tabular}{lrrr}
\hline Country & $\begin{array}{r}\text { Onshore } \\
\text { international }\end{array}$ & $\begin{array}{r}\text { All onshore } \\
\text { students }\end{array}$ & $\begin{array}{r}\text { Onshore international } \\
\text { as \% of all students }\end{array}$ \\
\hline Australia, 2009 (48 institutions) & & & 23 \\
\hline Total & 222,924 & 972,485 & 21 \\
\hline Mean & 4,644 & 20,260 & 14 \\
\hline Standard deviation & 3,895 & 14,569 & 65 \\
\hline RSD & 84 & 72 & \\
\hline
\end{tabular}




\begin{tabular}{lrrr}
\hline Country & $\begin{array}{r}\text { Onshore } \\
\text { international }\end{array}$ & $\begin{array}{r}\text { All onshore } \\
\text { students }\end{array}$ & $\begin{array}{r}\text { Onshore international } \\
\text { as \% of all students }\end{array}$ \\
\hline UK, 2010/2011 (154 institutions) & & & 17 \\
\hline Total & 426,600 & $2,491,440$ & 19 \\
\hline Mean & 2,770 & 16,178 & 13 \\
\hline Standard deviation & 2,265 & 18,348 & 66 \\
\hline RSD & 82 & 113 & 6.9 \\
\hline US, Fall 2010 (295 institutions) & & & 7.1 \\
\hline Total & 400,315 & $5,833,810$ & 6.1 \\
\hline Mean & 1,357 & 19,776 & 86 \\
\hline Standard deviation & 1,428 & 20,907 & 106 \\
\hline RSD & 105 & &
\end{tabular}

Next we make the same comparisons of all higher education institutions.

\section{Comparison of UK, US and Australia: all institutions}

All UK higher education institutions have on average 12,641 domestic students, almost three times the mean for all US institutions $(4,408)$ and almost double the mean for all Australian institutions $(6,948)$ (Table 16). This is because the UK has very few non doctoral granting institutions in contrast to the US which has a large number of very small non doctoral granting institutions. Consequentially, while all UK higher education institutions had considerable variation in their total enrolments with a relative standard deviation of 138, this was rather less than Australia (153) and much less than the US (201). Similarly in domestic postgraduates as a proportion of all domestic students: the UK is not so variable with a coefficient of 85 , and much less so than Australia (128) and the US (135). The UK has a large number of small institutions with substantial postgraduate enrolments, such as the performing arts academies, and has no institution with no postgraduate student. In contrast, 40 or over a third of Australian institutions had no domestic postgraduate enrolment in 2009. So the UK's proportion of domestic postgraduate students has a substantially lower relative standard deviation

Table 16: summary statistics for Australian, UK and US higher education institutions' domestic higher education enrolments by broad level

\begin{tabular}{|c|c|c|c|c|}
\hline Country & Postgrad & Undergrad & Total & $\begin{array}{r}\text { Postgrad as \% } \\
\text { of total }\end{array}$ \\
\hline \multicolumn{5}{|c|}{ Australia, 2009 (114 institutions) } \\
\hline Total & 197,619 & 594,408 & 792,027 & 25 \\
\hline Mean & 1,734 & 5,214 & 6,948 & 21 \\
\hline Standard deviation & 2,910 & 7,878 & 10,614 & 27 \\
\hline Relative standard deviation & 168 & 151 & 153 & 128 \\
\hline \multicolumn{5}{|c|}{ UK, 2010/2011 (164 institutions) } \\
\hline Total & 375,030 & $1,698,040$ & $2,073,070$ & 18 \\
\hline Mean & 2,287 & 10,354 & 12,641 & 23 \\
\hline Standard deviation & 2,108 & 16,044 & 17,482 & 19 \\
\hline Relative standard deviation & 92 & 155 & 138 & 85 \\
\hline \multicolumn{5}{|c|}{ US, Fall 2010, (2,945 institutions) } \\
\hline Total & $2,659,013$ & $10,321,078$ & $12,980,091$ & 21 \\
\hline Mean & 903 & 3,505 & 4,408 & 23 \\
\hline Standard deviation & 2,255 & 7,527 & 9,236 & 31 \\
\hline Relative standard deviation & 250 & 215 & 210 & 135 \\
\hline
\end{tabular}


The average size of all UK higher education institutions of 15,252 students is rather bigger than that for Australian higher education institutions $(9,868)$ and much bigger than the US $(4,613)$ (Table 17). This is because the UK has very few private institutions, which tend to be small, and the US has very many. There is reasonable variation in UK institutions' number of full time and total students, but rather less than Australia and much less than the US. This is because all but three or 2.6 per cent of Australia's 114 higher education institutions enrolled some part time students. In contrast 279 or 9.5 per cent of US higher education institutions enrolled only full time students. UK institutions have considerable variation by part time students because of the Open University. However, by proportion of full time students Australian institutions have more variation than both the UK and the US. This is because Australia has several private higher education institutions with only 20 per cent full time students and several more with fewer than half full time students.

Table 17: summary statistics for Australian, UK and US higher education institutions by broad study load

\begin{tabular}{|c|c|c|c|c|}
\hline Country & Full time & Part time & Total & $\begin{array}{l}\text { Full time as \% } \\
\text { of total }\end{array}$ \\
\hline \multicolumn{5}{|c|}{ Australia, 2009 (114 institutions) } \\
\hline Total & 794,452 & 340,414 & $1,134,866$ & 70 \\
\hline Mean & 6,908 & 2,960 & 9,868 & 66 \\
\hline Standard deviation & 10,832 & 4,481 & 14,895 & 24 \\
\hline Relative standard deviation & 157 & 151 & 151 & 36 \\
\hline \multicolumn{5}{|c|}{ UK, 2010/2011 (164 institutions) } \\
\hline Total & $1,677,345$ & 823,955 & $2,501,300$ & 67 \\
\hline Mean & 10,228 & 5,024 & 15,252 & 75 \\
\hline Standard deviation & 7,604 & 16,348 & 18,146 & 16 \\
\hline Relative standard deviation & 74 & 325 & 119 & 22 \\
\hline \multicolumn{5}{|c|}{ US, Fall 2010, (2,945 institutions) } \\
\hline Total & $9,902,860$ & $3,683,585$ & $13,586,445$ & 73 \\
\hline Mean & 3,368 & 1,251 & 4,613 & 75 \\
\hline Standard deviation & 8,155 & 3,065 & 9,662 & 22 \\
\hline Relative standard deviation & 242 & 245 & 209 & 29 \\
\hline
\end{tabular}

UK and Australian higher education institutions have an average of over 2,000 international onshore students, almost ten times the average for the US (206) (Table 18).

International onshore students are 17 per cent for all onshore students in the UK, much higher than the US (4.5 per cent) but rather lower than Australia (24 per cent). UK institutions show less variation than Australian institutions and much less variation than US institutions in number of onshore international students, number of all onshore students and proportion of international students.

Table 18: summary statistics for Australian, UK and US higher education institutions' onshore international students as a proportion of all onshore students

\begin{tabular}{lrrr}
\hline Country & $\begin{array}{r}\text { Onshore } \\
\text { international }\end{array}$ & $\begin{array}{r}\text { All onshore } \\
\text { students }\end{array}$ & $\begin{array}{r}\text { Onshore international } \\
\text { as \% of all students }\end{array}$ \\
\hline Australia, 2009 (114 institutions) & & & 24 \\
\hline Total & 245,593 & $1,023,406$ & 27 \\
\hline Mean & 2,136 & 8,899 & 32 \\
\hline Standard deviation & 3,341 & 13,470 & 24 \\
\hline
\end{tabular}




\begin{tabular}{lrrr}
\hline Country & $\begin{array}{r}\text { Onshore } \\
\text { international }\end{array}$ & $\begin{array}{r}\text { All onshore } \\
\text { students }\end{array}$ & $\begin{array}{r}\text { Onshore international } \\
\text { as \% of all students }\end{array}$ \\
\hline Relative standard deviation & 156.5 & 151.4 & 120 \\
\hline UK, 2010/2011 (164 institutions) & & & 17 \\
\hline Total & 428,225 & $2,501,295$ & 19 \\
\hline Mean & 2,611 & 15,252 & 13 \\
\hline Standard deviation & 2,282 & 18,146 & 66 \\
\hline Relative standard deviation & 87.4 & 119.0 & 4.5 \\
\hline US, Fall 2010, (2,945 institutions) & & & 3.3 \\
\hline Total & 606,354 & $13,586,445$ & 6.4 \\
\hline Mean & 206 & 4,613 & 194 \\
\hline Standard deviation & 626.9 & $9,662.0$ & \\
\hline Relative standard deviation & 304.5 & 209.4 & \\
\hline
\end{tabular}

\section{Discussion}

On the statistical measures considered here there is somewhat more variation in UK doctoral granting institutions than Australian doctoral granting institutions but rather less variation than US doctoral granting institutions. While Australia has some small specialized religious doctoral granting institutions, the UK has more in other specialized fields such as the creative arts and the US has several small specialized graduate doctoral granting universities. Very big and distinctive institutions such as the UK's Open University with 208,400 part time students, Oxford Brookes University with 239,945 offshore international students and the University of Phoenix with 307,965 full time students greatly increase the statistical variation in institutions' enrolments measured by the relative standard deviation.

Australia has long modelled its higher education on UK higher education, and more recently the two countries have followed similar directions in their higher education. Australia followed the UK in establishing a binary divide between universities and non research higher education institutions (called polytechnics in the UK and colleges of advanced education in Australia) but dismantled its binary divide in 1988, some four years earlier than the UK dismantled its binary divide in 1992. However, Australia's dismantling was achieved by establishing a 'unified national system' of higher education which set conditions for being funded directly by the national government and for receiving block institutional research grants. The UK national government set no such condition, and accordingly it has several universities such as Cranfield and colleges and institutes of the University of London which would not have been granted full independent and research status in Australia's unified national system.

On the other hand, many Australian private providers expanded strongly with the explosion of international education from the mid 1990s. In 2005 the Australian Government extended government guaranteed and subsidized income contingent loans to private higher education institutions. This supported the growth of private higher education providers and their enrolments of domestic students, although it is difficult to calculate the extent of this effect because the providers were not previously required to report their enrolment data. A longitudinal study of Australia using the same method found that on the same measures considered here Australian higher education institutions became somewhat less varied from 1987, the year before the establishment of the unified national system of higher education, to 1999, a decade after the establishment of the unified national system. But by 2009 the expansion of private providers meant variation had increased on both 1987 and 1999 levels (Moodie, 2013b, p. 75). 
In contrast, the UK Government did not introduce income contingent loans until 2006. By the most recent data considered here the UK government had made income contingent loans accessible to students at few private institutions, and since places had been rationed to cap expenditure on tuition fee loans and student income support, income contingent loans for private providers in the UK were about as rare as Commonwealth supported places for private providers in Australia. Consequently, the UK has relatively few private higher education providers.

The US federal government first established student loans in the 1950s in response to Sputnik, and hence made them available only in engineering, science and education. The federal government greatly broadened and extended student loans in the 1960s. The US has therefore subsidized enrolments in private institutions for much longer than Australia and the UK and accordingly it has many more private institutions. Some US state governments distinguish between different types of higher education institutions which offer baccalaureates and the Carnegie Foundation introduced an influential categorisation of higher education institutions in 1973. But there has been no widespread categorization and recategorization of US higher education institutions similar to the establishment and dismantling of the binary divides in Australia and the UK.

Of course the statistical enrolment measures considered here offer a very limited and partial view of variations amongst higher education institutions. Other obvious non categorical variables that could be examined are of research performance. For example, Weingarten and colleagues (2013) included in their data set to inform the differentiation discussion in Ontario each institution's number of $\mathrm{PhDs}$ granted, sponsored research income, number of publications, number of citations and mean standardized h score, which is a combined measure of the number and citations of research publications (Hirsch, 2005). An author has an h index of 20 if they published 20 papers with at least 20 citations. Since citation rates vary markedly by discipline Weingarten and colleagues (2013, p. 13) used h scores standardized by discipline.

Another important characteristics of higher education institutions are the fields in which they teach and research, and this is often understood to be distinctive of many institutions. Lepori, Baschung and Probst (2010) analysed data on students, PhDs, staff and publication of 242 higher education institutions in Finland, Italy, the Netherlands, Norway, Switzerland and the United Kingdom. Fields of teaching and research are categories and an analysis may be sensitive to its categorization of fields. Lepori, Baschung and Probst grouped fields in four broad domains of medical sciences, engineering and technology, natural sciences, and social sciences and humanities. They found five categories of specialist higher education institutions and three categories of generalist institution: those with strong medicine, some medicine and no medicine (Lepori, Baschung and Probst, 2010, p. 86). An analysis of Australia's 37 public universities by ten fields' proportion of student load and research performance found considerable variation of institutions by field and that fields of teaching concentration and research performance do not coincide for most institutions (Moodie, 2013a). But arguably even this analysis is too general: the international standard classification of education (UNESCO, 2006, p. 41) has 25 fields of education and the Frascati manual (OECD, 2002) has 20 sub fields within six major fields for classifying research.

Notwithstanding its limitations this study it offers some evidence to evaluate Birnbaum's (1983, pp. 149-182) argument that government planning inhibits institutional diversity which Huisman (1995, p. 12) contrasts with the archetypical government regulation of higher education for diversity, the California master plan for higher education. We have seen that the variety of institutions in the US, Australia and the UK is associated with the availability of government grants and loans to help students and their parents pay for the cost of higher education. The US federal government has made its grants and loans available to students of 
private institutions equally with those of public institutions since the 1950s and 60s. This has supported a great variety of institutions by size and specialization. Australian private higher education institutions expanded greatly with the explosion of international education from the mid 1990s and were further supported with the availability of government guaranteed and subsidized loans for their students from 2005. This has supported moderate dispersion of enrolments amongst Australian institutions. There is much less variety amongst institutions in the UK where government loans and grants to students of private institutions have been much more limited.

If this is right two propositions may be suggested. First, the extent of government involvement in higher education isn't so important for institutional variety as the form which it takes. Birnbaum observed high diversity amongst US institutions and that this didn't change noticeably despite a great expansion of the sector over two decades. But of course the diversity of US institutions at the first stage of Birnbaum's study in 1960 was supported by federal financial aid and the expansion of the sector and the maintenance of its diversity was importantly financed by extensive government involvement. More tentatively, one may suggest that the more limited the range of institutions for which government funding is available directly or indirectly the stronger government involvement is needed to have variety among the limited range of institutions for which government financial support is available.

\section{Acknowledgements}

I thank two anonymous reviewers for Higher Education Quarterly for their careful reading of an earlier draft of this manuscript and for their detailed (though contradictory!) suggestions for its improvement, all of which I have sought to follow. I also thank the editors for their encouragement and guidance in responding to the reviewers' comments.

\section{References}

Andrews, L., Aungles, P., Baker, S. and Sarris, A. (1998) Characteristics and performance of higher education institutions (A preliminary investigation). Canberra: DEETYA. http://citeseerx.ist.psu.edu/viewdoc/download?doi=10.1.1.86.1610\&rep=rep1\&type=pdf, last accessed 4 August 2013.

Birnbaum, R. (1983) Maintaining diversity in higher education. San Francisco: Jossey-Bass.

Conway, C., Zhao, H. and Montgomery, S. (2011) The NSSE national data project report. Toronto: Higher Education Quality Council of Ontario, http://www.heqco.ca/en$\mathrm{ca} /$ research/research\%20publications/Pages/Summary.aspx?link=01\&title=The\%20NSSE\%20 National\%20Data\%20Project\%20Report, last accessed 4 August 2013.

Hirsch, J. E. (2005) An index to quantify an individual's scientific research output. Proceedings of the National Academy of Sciences of the United States of America, volume 102, pages 16569-16572.

Huisman, J. (1995) Differentiation and diversity in higher education systems. Center for Higher Education Policy Studies, University of Twente.

http://www.academia.edu/280441/Differentiation_Diversity_and_Dependency_In_Higher_Ed ucation_A_Theoretical_and_Empirical_Analysis, last accessed 3 August 2013.

Huisman, Jeroen (2000) Higher education institutions: as different as chalk and cheese? Higher Education Policy, volume 13, pages 41-53. 
Huisman, J., Meek, L. and Wood, F. (2007) Institutional diversity in higher education: a crossnational and longitudinal analysis. Higher Education Quarterly, 61 (4), pp. 563-577.

Lepori, B., Baschung, L. and Probst, C. (2010) Patterns of subject mix in higher education institutions: a first empirical analysis using the AQUAMETH database. Minerva, 48, pp. 7399.

Moodie, G. (2013a) Australian public universities’ diversity onshore by broad fields of education. Melbourne: Martin Institute. http://www.lhmartininstitute.edu.au/insightsblog/2013/08/141-australian-public-universities-diversity-onshore-by-broad-fields-ofeducation, last accessed 10 August 2013.

Moodie, G. (2013b) System uniformity, The Dawkins revolution 20 years on. Croucher, G, Marginson, S., Norton, A. and Wells, J. (eds.). Carlton: Melbourne University Press, pp. 75-90.

Morphew, C.C. (2009) Conceptualizing change in the institutional diversity of U.S. colleges and universities. The Journal of Higher Education, 80 (3), pp. 243-269.

Nature Education (2013) Glossary. http://www.nature.com/scitable/definition/species-312, last accessed 4 August 2013.

OECD (Organisation for Economic Co-operation and Development) (2002) Frascati Manual: proposed standard practice for surveys on research and experimental development, 6th edition. Retrieved 27 May 2012 from www.oecd.org/sti/frascatimanual

OECD (Organisation for Economic Co-operation and Development) (2013) Classification of tertiary programmes, Chapter A: The output of educational institutions and the impact of learning, Annex 3: Sources, methods and technical notes, Education at a Glance. OECD Indicators 2013. http://www.oecd.org/edu/eag.htm, last accessed 26 June 2013.

Rossi, F. (2009) Increased competition and diversity in higher education: an empirical analysis of the Italian university system. Higher Education Policy, 22 (4), pp. 389-413.

Rossi, F. (2010) Massification, competition and organizational diversity in higher education: evidence from Italy. Studies in Higher Education, 35 (3), pp. 277-300.

Stanley, G. and Reynolds, P. (1994) Similarity grouping of Australian universities. Higher Education, 27 (3), pp. 359-366.

The British Ecological Society (2013) About ecology.

http://www.britishecologicalsociety.org/about-ecology/, last accessed 4 August 2013.

UNESCO (United Nations Educational, Scientific and Cultural Organization) (2006) International Standard Classification of Education. ISCED 1997. http://www.uis.unesco.org/Education/Pages/international-standard-classification-ofeducation.aspx, last accessed 22 March 2012.

Weingarten, H. P., Hicks, M., Jonker, L. and Liu, S. (2013) The diversity of Ontario’s universities: a data set to inform the differentiation discussion. Toronto: Higher Education Quality Council of Ontario. http://www.heqco.ca/enCA/Research/Research\%20Publications/Pages/Summary.aspx?link=108, last accessed 24 July 2013. 